\title{
THE EFFECT OF ENVIRONMENT CHARACTERISTICS ON DIARRHEA OCCURRENCE AMONG CHILDREN UNDER FIVE IN PALEMBANG
}

\author{
Amrina Rosyada, Dini Arista Putri, Nur Alam Fajar, \\ Faculty of Public Health, Universitas Sriwijaya
}

\begin{abstract}
Diarrhea is still a public health problem in developing countries such as Indonesia because morbidity and mortality rates are still high in these areas. A morbidity survey conducted by the Diarrhea Department of the Ministry of Health in Indonesia between 2000 and 2010 shows rising incidences of diarrhea in children. In 2000, Incidence Rate (IR) diarrhea incidents occurred in 301/1000 members of the population, and this increased to 411/1000 in 2010. Cases of diarrhea have become dangerous when suffered by infants because the mortality rate will increase because weaker immunity than olders. Environmental factors such as water, waste, and toilet contribute greatly to cases of diarrhea; therefore, in this research, we analyze environmental characteristics' effects on the incidence of diarrhea in infants in Palembang. This study uses a mixed-method design combining quantitative data collection using secondary data from the Department of Health with qualitative data collection using in-depth interviews of Palembang's local government and health center personnel in the districts with the highest and lowest cases of diarrhea. Quantitative data analysis are visualized in the form of a map, while qualitative data are analyzed using content analysis. The results show that Ilir Timur I has the highest incidences of diarrhea while the Sako district has the lowest. Based on the results of the analysis, Ilir Timur I has more cases of diarrhea largely because of its non-working area health centers. Sako has the fewest cases of diarrhea because the clinics, doctors, and midwives in private practice in the region of Sako do not report the cases, as well as because of factors related to access remote health centers. Therefore, interventions based on health data for diarrhea need to be restyled for a drastic reduction of diarrhea cases.
\end{abstract}

Keywords: Area, diarrhea, children, characteristic, environment, data

\section{PENGARUH KARAKTERISTIK LINGKUNGAN TERHADAP KEJADIAN DIARE PADA ANAK-ANAK DI BAWAH LIMA TAHUN DI PALEMBANG}

\begin{abstract}
ABSTRAK
Diare masih merupakan masalah kesehatan masyarakat di negara berkembang seperti Indonesia karena angka kesakitan dan kematian masih tinggi di daerah ini. Sebuah survei morbiditas yang dilakukan oleh Departemen Diare Kementerian Kesehatan di Indonesia antara tahun 2000 dan 2010 menunjukkan meningkatnya insiden diare pada anak-anak. Pada tahun 2000, Incidence Rate (IR) diare mencapai 301/1000 anggota penduduk dan meningkat menjadi 411/1000 pada tahun 2010. Kasus diare menjadi berbahaya ketika diderita oleh bayi karena angka kematian akan meningkat akibat kekebalan yang lebih lemah dibandingkan orang dewasa. Faktor lingkungan seperti air, limbah, dan WC berkontribusi besar terhadap kasus diare; Oleh karena itu, dalam penelitian ini, kami menganalisis efek karakteristik lingkungan pada kejadian diare pada bayi di Palembang. Penelitian ini menggunakan desain mix-method yaitu menggabungkan pengumpulan data kuantitatif menggunakan data sekunder dari Kementrian Kesehatan dan pengumpulan data kualitatif menggunakan wawancara mendalam dari pihak kecamatan dan staf puskesmas di kabupaten yang memiliki kasus diare tertinggi dan terendah . Analisis data kuantitatif divisualisasikan dalam bentuk peta, sedangkan data kualitatif dianalisis menggunakan analisis isi. Hasil penelitian menunjukkan bahwa Ilir Timur I memiliki insiden diare tertinggi sedangkan Kabupaten Sako memiliki insiden terendah. Berdasarkan hasil analisis, Ilir Timur I memiliki lebih banyak kasus diare karena banyak kasus berasal dari luar wilayah kerja puskesmas. Sako memiliki kasus diare paling sedikit karena klinik, dokter, dan bidan yang berpraktik swasta di wilayah Sako tidak melaporkan kasus. Selain itu, puskesmas Sako berada di tempat yang terpencil. Oleh karena itu, upaya intervensi puskesmas perlu mencermati data yang didapat agar program lebih tepat sasaran. Upaya menggalakkan pelaporan dari pihak swasta juga perlu dilakukan.
\end{abstract}

Kata kunci: Area, diare, anak-anak, karakteristik, lingkungan, data

Correspondece Address: Amrina Rosyada Jl. Palembang Prabumulih KM 32, Indralaya Kabupaten Ogan Ilir, Sumatera Selatan Email: arosyadaeffendy@gmail.com 


\section{INTRODUCTION}

According to the World Health Organization (WHO), diarrhea is a disease characterized by changes in the shape and consistency of stools, making them soft or liquid, and increased frequency of bowel movements to 3 or more per day, which may be accompanied by vomiting or bloody stools. 1 Clinical causes of diarrhea can be grouped into six major categories: infection, malabsorption, allergies, toxicity, immunodeficiency, and miscellaneous. The most common causes of diarrhea are infection and poisoning. Of the 174,735 incidences of diarrhea in South Sumatra Province in 2014, $97.16 \%$ were successfully handled at diarrhea health facilities. This indicates that $2.84 \%$ of diarrhea incidences in 2014 were not handled. ${ }^{2}$ Palembang is the capital city of South Sumatra Province, consisting of sixteen districts: Ilir Timur I, Ilir Timur II, Ilir Barat I, Ilir Barat II, Seberang Ulu I, Seberang Ulu II, Sukarame, Sako, Bukit Kecil, Gandus, Kemuning, Kalidoni, Plaju, Kertapati, AlangAlang Lebar, and Sematang Borang. Based on the data from the Palembang Health
Department in 2014, there were 44,213 cases of diarrhea; the highest number of diarrhea cases came from Seberang Ulu I and the lowest number of cases came from AlangAlang Lebar, Sako, Seberang Ulu II, Gandus, Sematang Borang, and Plaju. ${ }^{3}$ Palembang areas mostly consist of local rivers and swamps. Marsh areas are generally characterized by the formation of a basin that is more spacious, with a depth and puddle that are relatively shallow. However, the watershed, including the plains overflow of flood (flood plain), which forms hollow, elongated valleys also has a stream formed by the main river and its tributaries. ${ }^{4}$

This research was conducted by observing and studying environmental characteristics, population factors, and land use, especially in the city of Palembang, which is associated with incidences of diarrhea. Environmental characteristics studied include sources of drinking water, use of latrines, and waste management, which are potential risk factors for diarrhea, and they are used to determine the spread of diarrhea in Palembang.

\section{METHOD}

This study uses a mixed-method design combining quantitative and qualitative data to enrich interpretation of the results. For qualitative we use semi-structured interviews that before we do interviews we provide informed consent.

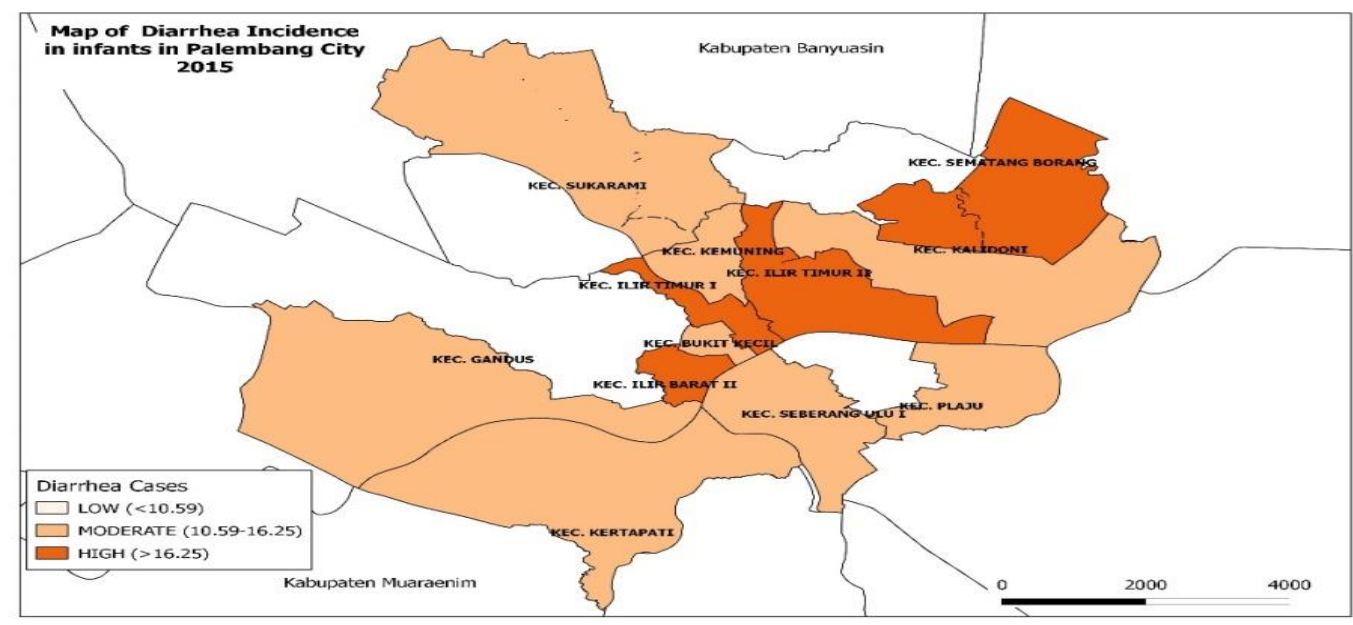

Figure 1.

Map of Dairrhea Incidence in Infants in Palembang City 2015 
For quantitative, we used secondary data from health departments' in Palembang. Study data comes from the city of Palembang, specifically the Ilir Timur I and Sako districts, from August to November 2016. A quantitative design is used to determine the magnitude and pattern of diarrhea in children (0-59 months) in Palembang and its relation to territorial factors, whereas a qualitative design is used for more detailed information related to the environmental characteristics of the areas and the incidences of diarrhea. The qualitative portion relies on 8 interviews from diarrhea program officer and health promotion officers at primary health centers in Dempo, Ariodillah, and Talang Ratu in Ilir Timur I and Sako.

For the quantitative portion, we collected secondary data from health departments' 2015 records about children's diarrhea. We use content analysis for qualitative data and for quantitative we do mapping using Quantum GIS 1.8.0

\section{RESULTS \\ Cases of Diarrhea in Palembang}

In the effort to control diarrheal diseases in Palembang, incidences of diarrhea in infants indicate the success or failure of the diarrhea program from Palembang Health Department. In 2015, the Palembang Health Department set target coverage of diarrhea in infants at $20 \%$ across the 39 health centers. ${ }^{5}$ However, only 6 health centers have been able to achieve this target coverage. Based on the average data of diarrhea cases, Ilir Timur I has the highest number of cases and Sako has the lowest number of cases. ${ }^{5}$

\section{Figure 1. Case distribution of diarrhea in Palembang 2015}

Based on the administrative map above, cases of diarrhea in Palembang are categorized as being low, medium, or high.
The low category indicates a region with $<10.59$ cases, as in Seberang Ulu II, Ilir Barat I, Alang-Alang Lebar, and Sako. The medium category indicates an average number of diarrhea cases in the range of 10.59-16.25 cases, as in Sukarami, Kalidoni, Kemuning, Bukit Kecil Plaju, Kertapati, and Seberang Ulu I. The high category indicates an average number of cases of diarrhea $>16.25$, as in Ilir Barat II, Ilir Timur I, Ilir Timur II, and Sematang Borang. ${ }^{1}$

\section{Characteristics of Ilir Timur}

Interviews with local government representatives, health center representatives, and other public officials of Ilir Timur I support the observation that, in some areas, the Musi River basin drained in areas 13,14, and 16 Ilir Timur I. Serviced by the Dempo Health Center, areas 13 and 14 are classified as slum areas because housing in this area has little value and poor sanitation facilities. Of the areas serviced by the Ariodillah Health Center, the Pangeran River area behind Cinde Market still needs attention. As for the health centers in the region of Talang Ratu, 8 regions are still in need of coverage. Environmental conditions are worse in this area because of high housing density; many houses are stacked, with only 1.5-2 $\mathrm{m}$ of foundation. Additionally, seen from the level of sanitation latrines, garbage, and water use. Most communities in this district mostly already have their own latrines (usually swan neck toilets), and only a few people have latrines in the form of holes flowing into the ditch or gutter. Water is also largely obtained from PAM (Clean Water that Provide by Government) but there are still people who use wells in addition to PAM. In terms of waste disposal, most people use stacked for a certain time before it is picked up by waste officers.

\section{Characteristics of Sako}

Based on observations and in-depth 
interviews with public officials and community members, Sako is mostly a residential complex in which access to water, garbage, and latrines has been standardized. Therefore, Sako no longer has any slum areas, but there are still areas that still need improvements to sanitation because they include wetlands or swamp. Sako has four region, all of which rely on health centers located on Lematang Raya Street, Lebong Gajah District, Sematang Borang. There is adequate access to this health center because of its location in a remote area, and there is no public transportation because the clinic is located in a housing complex region.

\section{DISCUSSION}

\section{Analysis of the correlations of diarrhea incidence with the characteristics of Ilir Timur I}

Data from the health department shows that Ilir Timur I has a high number of cases of diarrhea. Based on the results of in-depth interviews with public health officials and community members, three significant observations have been made.

First, the diminished contributions of nonworking health centers in the area contribute to an increase in cases of diarrhea. This was discovered in in-depth interviews with health workers in the Talang Ratu health center. Based on calculations from health officials in 2015 , the number of diarrhea cases in Talang Ratu health center increased to $70 \%$ for people who do not live in the working area of the Talang Ratu health center. Therefore, any intervention undertaken by the clinic will not decrease the number of diarrhea cases significantly.

Second, the Ariodillah health center got the donation number of diarrhea cases from Charitas hospital. Cases of diarrhea at the Ariodillah health center comprise most of the cases in Ilir Timur I. However, the activities inside and outside the clinic have been implemented properly. Even home visits are often done by public officers to increase public health standards. The Ariodillah health center obtains case data from Charitas hospital in Palembang because the policy states that data from private hospital will report the the primary health care that closest to the private hospital location. Charitas is a large private hospital that serves patients from various regions. Therefore, the attempt to rescue the region-based clinics has not shown significant results because data from Charitas hospital come from many regions joined in data from Ariodillah promary health care in Ilir Timur 1 while primary health care program just focused with working area. So, to make program based on data is not valid.

Third, outdoor activities in the Dempo and Talang Ratu health centers only rely on the Integrated Service Post. Efforts to prevent diarrhea in the Dempo and Talang Ratu health centers are still heavily dependent on activities in the Posyandu. However, the Integrated Service Post primarily provides basic immunization services for children up to 9 months old. Beyond these activities, the percentage of mothers who bring their children to neighborhood health centers is significantly lower, even though diarrhea is very risky when suffered by children aged 0 59 months. It is possible to contribute to the case of diarrhea in this region.

\section{Analysis of the correlations of diarrhea incidences with the characteristics of Sako}

Based on the data from the Palembang health department, Sako is the district with the fewest incidences of diarrhea in Palembang. Data was obtained from the Integrated Service Post in Sako to determine the cause of the lower number diarrhea cases in Sako. Three major observations were made.

First, there is no coordination among health center personnel. Interviews with Sako's local government officials revealed that that districts do not have public health 
officers. Interviews were conducted with subdistrict officers, who only know the conditions of their own residence areas. In addition to the health center level, officers of health programs, environmental officers, and officers of health promotion do not have the coordination to handle the cases. Those between sections only know the information about the scope of the work itself. Therefore, information about diarrhea and its interventions is not fully known. ${ }^{6,7}$

Second, there is limited access to health centers. The Multiwahana Health Center in Sako includes 4 villages and is fairly difficult to access. The Multiwahana Health Center is in the region housing complex and there is no public transport that passes by the health center. Transportation options to get to the clinic are limited private vehicles, which are sometimes to be around health centers. However, motor tricycles themselves are not always around health centers and have a rate considerably higher than other public transport. This access could potentially lead to the unwillingness of the public to go to the clinic. ${ }^{8,9}$

Third, data about diarrhea is often underreported. Interviews with health service officers revealed that the low number of cases of diarrhea at the health center are due to underreporting rather than the center's program's success. Data about toddler diarrhea indicates that cases handled by private midwives, physicians in private practice, and private clinics are not reported to the health center, leading to the appearance that diarrhea cases in the district are few. Efforts to encourage private health centers to report cases have not received significant responses. ${ }^{10}$

The problem with Sako's primary health care is due to the lack of coordination among health officers. This also happened in 10 primary health care centers in Calabar, southeast Nigeria, where there is no supervision from coordinators and no coordination about child health programs. ${ }^{11}$ The problem in Dempo and Talang Ratu is that health promotion depends on the Integrated Service Post for children, and is not effective. This is similar to a case reported by Chang (1981) in which local health department do not provide pediatric services. ${ }^{12}$ Ilir Timur I and Sako have the highest and lowest number of cases of diarrhea though the regions have similar characteristics. Both have complex areas and villages, impassable streams, and similar access to water, waste disposal, and latrines. There are variations in individuals in their respective districts. Individual healthy lifestyles play an important role in diarrhea occurrence. ${ }^{13-20}$

\section{CONCLUSION}

Ilir Timur I and Sako have the highest and lowest number of cases of diarrhea though the regions have similar characteristics. Both have complex areas and villages, impassable streams, and similar access to water, waste disposal, and latrines. There are variations in individuals in their respective districts. The factors that lead to more cases of diarrhea in Ilir Timur I include the district's non-working health centers. Sako appears to have the fewest cases of diarrhea because clinics, doctors, and midwives in private practice in Sako do not report related cases and because there is better access to health centers. Thank to the Science and Technologi Science Grant (SATEK UNSRI) from Sriwijaya University that has provided funding for the implementation of this research and for Mr. Iwan Stia Budi, SKM., MKM asa a dean of public health faculty that had give permission to do this research. 


\section{REFERENCES}

1. Dinas Kesehatan Kota Palembang. Capaian Diare Balita Puskesmas 20132015. Palembang, Sumatera Selatan; 2016.

2. Kementrian Kesehatan RI. Profil Kesehatan Indonesia. Jakarta; 2015.

3. Dinas Kesehatan Provinsi Sumatera Selatan. Profil Kesehatan Sumatera Selatan 2014. Palembang; 2014.

4. Badan Aplikasi Ilmu Pengetahuan Dan Teknologi Sriwijaya. Rencana Pembangunan Jangka Panjang (Rpjp) Kota Palembang 2005-2025. Palembang; 2006.

5. Dinas Kesehatan Kota Palembang. Profil Kesehatan Kota Palembang. Palembang, Sumatera Selatan; 2015.

6. Indriani RA. Analisis Pelaksanaan Program Diare di Puskesmas Deli Kecamatan Medan Deli Tahun 2014. Universitas Sumatera Utara; 2014.

7. Rukmini, Syahrul F. Analisis Sistem Surveilans Diare Puskesmas Tambakrejo Kota Surabaya. Bul Penelit Sist Kesehat. 2011;14(2):13645.

8. Murniati. Faktor-faktor yang Berhubungan dengan Pemanfaatan Pelayanan Antenatal oleh Ibu Hamil di Kabupaten Aceh Tenggara. Universitas Sumatera Utara; 2008.

9. M R. Faktor yang Berhubungan dengan Kejadian Diare pada Balita di Beberapa Regional Indonesia Tahun 2007. Bul Penelit Kesehat. 2010;2431 .

10. Zahroh R, Rahmawati R, Abd. Rachman IM. Pendidikan Kesehatan Meningkatkan Perilaku Pencegahan Diare pada Keluarga Tahap 3. Journals Ners Community. 2013;4(2):113-20.

11. Ehiri JE, Anyanwu EC, Meremikwu MM, Ikpeme MB. Quality of child health services in primary health care facilities in south-east Nigeria. 2005;181-92.

12. Chang A. Primary Health Care for Urban Children and Youth: The Role of Local Health Departments. 1979;69-72.

13. Adisasmito W. Faktor Risiko Diare Pada Bayi dan Balita di Indonesia: Sysmatic Review Penelitian Akademik. Makara Kesehat. 2007;11(1):1-10.

14. Kasnodihardjo, Elsi E. Deskripsi Sanitasi Lingkungan, Perilaku Ibu , dan Kesehatan Anak. J Kesehat Masyarrakat Univ Indones. 2013;7(9):415-20.

15. Mafazah L. Ketersediaan Sarana Sanitasi Dasar, Personal Hygine Ibu dan Kejadian Diare. J Kesehat Masy Unnes. 2013;8(2):176-82.

16. Sujaya I, Aryantini DN, Nursini N, Purnama S, Dwipayanti N, Artawan I, et al. Identifikasi Penyebab Diare di Kabupaten Karangasem , Bali. J Kesehat Masyarrakat Univ Indones. 2010;4(4):187-92.

17. L M. Hubungan Sanitasi Lingkungan dengan Angka Kejadian Diare pada Balita di Wilayah Kerja Puskesmas Meuraxa Tahun 2016. Serambi Saintia. 2016;4(2).

18. Sharfina H, F R, Rosadi D. Pengaruh Faktor Lingkungan dan Perilaku terhadap Kejadian Diare pada Balita di Wilayah Kerja Puskesmas Sungai Tabuk Kabupaten Banjar. J Publ Kesehat Masy. 2016;3(3).

19. Ferliando HT, Asfawi S. Hubungan antara Sanitasi Lingkungan dan Personal Hygene Ibu dengan Kejadian Diare pada Balita di Wilayah Kerja Puskesmas Mangkang. Visikes J Kesehat. 2015;14(2):91-182.

20. K L, Suhartono, W NE. Hubungan Praktek Personal Hygene Ibu dan Kondisi Sanitasi Lingkungan Rumah dengan Kejadian Diare pada Balita di Puskesmas Kampung Dalam Kecamatan Pontianak Timur. J Kesehat Lingkung Indones. 2012;11(1). 